\title{
Efektivitas skor LATCH sebagai alat penilaian menyusui: scoping review
}

\section{Effectiveness of LATCH scores as the assessment tool of breastfeeding: scoping review}

\author{
Esti Rahayu $^{1 *}$, Herlin Fitriana Kurniawati ${ }^{2}$, Herlin Fitriani Kurniawati ${ }^{3}$ \\ ${ }^{1,2,3}$ University 'Aisyiyah Yogyakarta, Ringroad Barat No.63 Nogotirto Street, Gamping, Sleman, Yogyakarta, \\ 55292, Indonesia \\ 1estirahayu2006@gmail.com*; ${ }^{2}$ herlinana@unisayogya.ac.id; ${ }^{3}$ herlinani@unisayogya.ac.id \\ *corresponding author \\ Tanggal Submisi: 22 Maret 2021; Tanggal Penerimaan: 14 Juni 2021
}

\begin{abstract}
Abstrak
Penelitian ini bertujuan untuk mengetahui efektifitas dan kelemahan skor LATCH sebagai alat penilaian pemberian ASI. Metode penelitian dengan menggunakan lima langkah untuk tinjauan pelingkupan digunakan dalam tinjauan ini. Temuan dalam penelitian ini adalah skor LATCH digunakan secara efektif sebagai alat penilaian menyusui. Skor LATCH dapat menilai tentang perlekatan, suara menelan, bentuk puting susu, tingkat kenyamanan ibu, posisi bayi dan dapat memprediksi lamanya menyusui.
\end{abstract}

Kata kunci: skor LATCH; alat penilaian; teknik menyusui

\begin{abstract}
This study aims to find out the effectiveness and weakness of the LATCH score as assessment tool of breastfeeding. The research methode was using five steps for scoping review were used in this review. The finding of this study was that the LATCH score was used effectively as a breastfeeding assessment tools. The LATCH score could assess about attachment, sound of swallowing, the shape of nipple, mother's comfort level, the position of infant and can predict the duration of breastfeeding.
\end{abstract}

Keywords: LATCH score; assessment tools; breastfeeding techniques

\section{INTRODUCTION}

WHO and UNICEF recommend to give optimal nutrition for newborns through a program of exclusive breastfeeding for six months (Heird, 2012). The America Academy of Pediatrics recommends exclusive breastfeeding for babies for a minimum of 6 months and it can be continued at least until the baby is 12 months old. Breast milk is the best nutrition and it is intended specifically for newborns because it consists of various antibody components, complete nutrition and is easily digested by newborns compared to formula milk (Altuntas et al., 2015).

Data related to the number of exclusive breastfeeding from 2013 to 2018 was still very low from the set standards, $43 \%$ of newborns who started 
breastfeeding in the first hour after birth and $41 \%$ of babies under the age of six months who received exclusive breastfeeding. Meanwhile, $70 \%$ of women still breastfeed their babies until they are one to two years old and the breastfeeding level has decreased until 45\% (UNICEF, 2019).

The nutrient content of breast milk is not necessarily found in formula milk, so then the government truly recommends the exclusive breastfeeding due to it has many benefits for the growth and development of infant (Dennis et al., 2012). Besides, the appropriate breastfeeding process, the infant will get good physical, emotional, and spiritual development in its lives (Wagner et al., 2013). It is contrary to the recommendation of exclusive breastfeeding, data from the Indonesian Demographic and Health Survey shows a decrease in the exclusive breastfeeding coverage rate from $40.3 \%$ in 1997 to $39.5 \%$ in 2007. In 2012, the coverage of exclusive breastfeeding increased to $42 \%$. and it increased to $52.3 \%$ in 2014, but this increase still does not meet with the target of Ministry of Health such as increasing the coverage to $80 \%$ by 2014 (Kemenkes RI, 2014).

Postpartum mothers who have just given birth, they usually describe the first few weeks of breastfeeding as a very difficult time, with many unexpected problems that emerge (Wagner et al., 2013). The research conducted by (Tauriska, 2015) reveals that the correct attachment will produce the right suction of infant. If the suction of infant is correct, it will stimulate the hypothalamus which will stimulate the anterior pituitary gland to produce prolactin and the posterior pituitary to produce the hormone oxytocin (Brown et al., 2014). If the suction of baby is correct, it will be characterized by rounded cheeks, more areola above the mouth, slow, deep and resting suction, can be heard when the baby swallows. Research (Abbas \& Hasan, 2015) argue that the skills of breastfeeding babies can be mastered naturally in every mother, mothers must still understand good and correct techniques during breastfeeding to babies. It is often failure to breastfeed due to the wrong position and placement of the baby.

Several instruments for assessing breastfeeding techniques have been developed for a long time to identify breastfeeding problems. The LATCH score is one of the breastfeeding instruments that is often used because it is simple and assesses Latch, Audible swallowing, Type of nipple, Comfort, and Hold (LATCH) (Altuntas et al., 2014).

\section{METHODS}

This review uses a methodology for grouping reviews as suggested by Arksey and O'Malley. The stages carried out in this scoping review consist of identifying research questions, identifying relevant studies, selecting studies, data charting, compiling, summarizing and reporting the results (Arksey \& Malley, 2005).

\section{Identifying research questions (stage 1)}

For this scoping review, the authors focus on two research questions. The first is the LATCH Score effective as a breastfeeding assessment tool? And the second is what are the weaknesses of the LATCH score as a breastfeeding assessment tool?

\section{Identifying relevant studies (stage 2)}


In conducting a relevant study search, the author uses 3 databases including Pubmed, ScienceDirect and EBSCO by using keywords that the author has identified relating to the topic of scoping review in the search process. The keywords that are the keywords in the search process include (LATCH) OR "LATCH Score") OR "assessment tools") AND "breastfeeding techniques") AND "postpartum women") OR "postnatal women". And add supporting keywords and keywords others that are equivalent words from the main keywords to broaden the search then organize and filter the years on the page such as filtering, namely Abstract, Human and English. In Table. 1 there is a table to identify relevant articles using the following inclusion and exclusion criteria:

Tabel 1. Inclusion criteria and exclusion criteria

\begin{tabular}{lll}
\hline Inclusion criteria & \multicolumn{2}{l}{ Exclusion criteria } \\
\hline a. Articles published in a. Opinion article & \\
English or Indonesian & & b. Letters and book \\
b. Original Article & reviews \\
c. Documents / reports / & \\
draft policies / guidelines & c. Mother's perception of \\
from WHO / certain & partner support during \\
formal organizations & breastfeeding \\
d. Breastfeeding assessment & \\
tool published in & \\
e. Article pon-2019 & \\
&
\end{tabular}

\section{Study selection (stage 3 )}

The results of a literature study of 3 data bases, then conducted a thorough title identification of the data based using identified keywords and obtained as many as 537 articles that the authors considered could contribute data related to the results to be achieved by the author. The next step was 537 articles to be screened, to see whether the articles obtained were in accordance with the criteria sought, the authors were oriented to the inclusion and exclusion criteria set out in table 1 in diagram 1. 


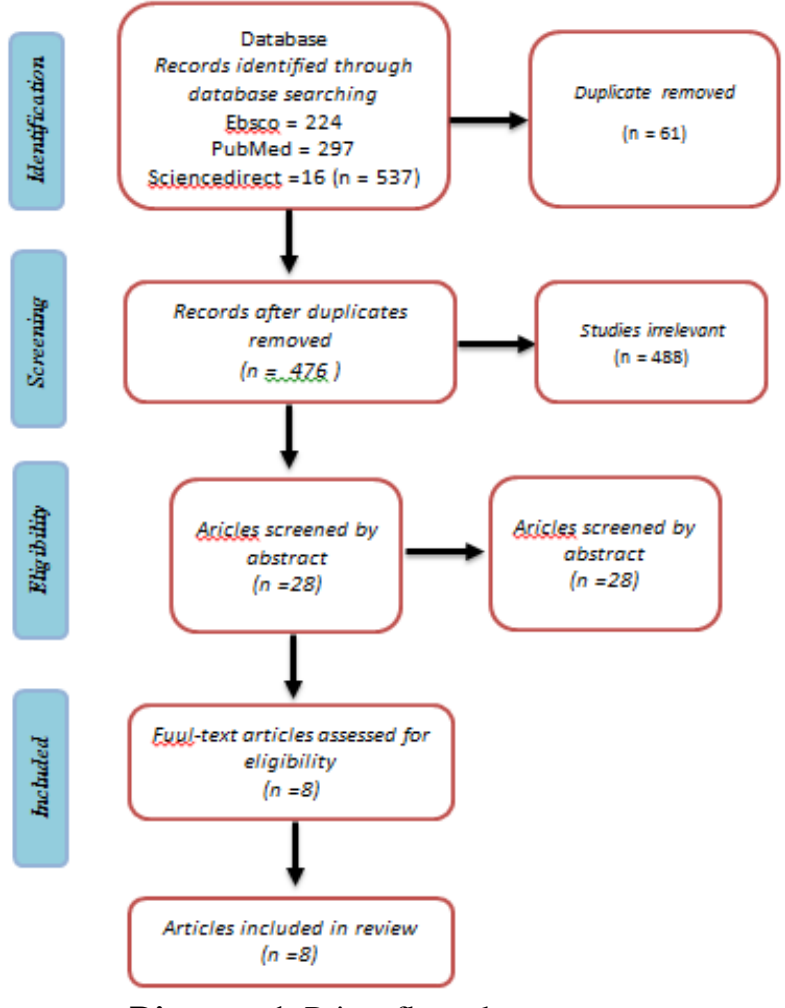

Diagram 1. Prism flow chart

\section{Data charting (stage 4)}

8 The selected article is then carried out a critical appraisal process using the Hawker checklist tools. In scoping review, the study quality is not the main concern, but rather in the effort to find the flexibility and informality of the information contained in it, but other studies reveal that the assessment of the quality of articles in a scoping review is actually able to identify fundamental gaps in terms of evidence.

The next step is to collect and sort key information from the selected articles such as title/author/year/grade, country, aim, type of research, data collection, participants / size and results then described in table 2. 
Charting data from several articles is then taken 8 articles to do charting data.

\begin{tabular}{|c|c|c|c|c|c|c|c|}
\hline No & $\begin{array}{l}\text { Title/Author } \\
\text { /Year/Score }\end{array}$ & Country & Objective & $\begin{array}{l}\text { Types of the } \\
\text { Research }\end{array}$ & $\begin{array}{l}\text { Data colleting } \\
\text { technique }\end{array}$ & $\begin{array}{l}\text { Participan } \\
\text { ts/Sample } \\
\text { size }\end{array}$ & Result \\
\hline 1 & $\begin{array}{l}\text { Comparison of the } \\
\text { breastfeeding patterns } \\
\text { of mothers who } \\
\text { delivered their babies } \\
\text { per vagina and via } \\
\text { cesarean section: An } \\
\text { observational study } \\
\text { using the LATCH } \\
\text { breastfeeding charting } \\
\text { system (Havva Cakmak } \\
\text { \& Sema Kuguoglu, } \\
\text { 2006) (Cakmak \& } \\
\text { Kuguoglu, 2007) }\end{array}$ & Turkey & $\begin{array}{l}\text { To determine the } \\
\text { difference in the } \\
\text { breastfeeding } \\
\text { process between } \\
\text { postpartum sectio } \\
\text { caesarean and } \\
\text { postpartum vaginal } \\
\text { mothers. }\end{array}$ & $\begin{array}{l}\text { Quantitative } \\
\text { (Prospective } \\
\text { Cohort } \\
\text { Study) }\end{array}$ & $\begin{array}{l}\text { Introductory } \\
\text { Information Form } \\
\text { and by using } \\
\text { Breastfeeding } \\
\text { Charting } \\
\text { (LATCH) }\end{array}$ & $\begin{array}{l}118 \\
\text { women } \\
\text { who } \\
\text { underwent } \\
\text { cesarean } \\
\text { delivery } \\
\text { and } 82 \\
\text { women } \\
\text { who went } \\
\text { through } \\
\text { vaginal } \\
\text { delivery }\end{array}$ & $\begin{array}{l}\text { From the results of the } \\
\text { study found that the type } \\
\text { of childbirth affects the } \\
\text { process of breastfeeding, } \\
\text { especially in women who } \\
\text { have a cesarean birth, in } \\
\text { need of more support and } \\
\text { assistance. }\end{array}$ \\
\hline 2 & $\begin{array}{l}\text { Does the LATCH Score } \\
\text { Assessed in the First } 24 \\
\text { Hours After Delivery } \\
\text { Predict Non-Exclusive } \\
\text { Breastfeeding at } \\
\text { Hospital Discharge } \\
\text { (Gianluca Tornese, } \\
\text { Luca Ronfani, Carla } \\
\text { Pavan, Sergio } \\
\text { Demarini, Lorenzo }\end{array}$ & Italia & $\begin{array}{l}\text { The aim is to see } \\
\text { the correlation } \\
\text { between the } \\
\text { assessment of } \\
\text { breastfeeding } \\
\text { techniques which is } \\
\text { assessed at } 24 \\
\text { hours first with a } \\
\text { few hours after } \\
\text { giving birth. }\end{array}$ & $\begin{array}{l}\text { Quantitative } \\
\text { (Prospective } \\
\text { Cohort } \\
\text { Study) }\end{array}$ & Medical records & $\begin{array}{l}299 \text { pairs } \\
\text { of mothers } \\
\text { and babies }\end{array}$ & $\begin{array}{l}\text { The breastfeeding } \\
\text { assessment tool is an } \\
\text { assessment tool } \\
\text { capable of assessing } \\
\text { mothers and babies } \\
\text { who might benefit } \\
\text { from national } \\
\text { support in certain } \\
\text { categories of risk }\end{array}$ \\
\hline
\end{tabular}




\begin{tabular}{|c|c|c|c|c|c|c|c|}
\hline No & $\begin{array}{l}\text { Title/Author } \\
\text { /Year/Score }\end{array}$ & Country & Objective & $\begin{array}{l}\text { Types of the } \\
\text { Research }\end{array}$ & $\begin{array}{l}\text { Data colleting } \\
\text { technique }\end{array}$ & $\begin{array}{l}\text { Participan } \\
\text { ts/Sample } \\
\text { size }\end{array}$ & Result \\
\hline & $\begin{array}{l}\text { Monasta, and Riccardo } \\
\text { Davanzo, 2012) } \\
\text { (Tornese et al., 2012) }\end{array}$ & & & & & & $\begin{array}{l}\text { breastfeeding is not } \\
\text { exclusive when } \\
\text { finished treatment. } \\
\text { Future research } \\
\text { related to an } \\
\text { assessment tools, } \\
\text { breastfeeding } \\
\text { techniques are able } \\
\text { to predict the } \\
\text { duration of } \\
\text { breastfeeding if done } \\
\text { early in life. }\end{array}$ \\
\hline 3 & $\begin{array}{l}\text { LATCH Score as a } \\
\text { Predictor of Exclusive } \\
\text { Breastfeeding at } 6 \\
\text { Weeks Postpartum: A } \\
\text { Prospective Cohort } \\
\text { Study (Sowjanya and } \\
\text { Lakshmi Venugopalan, } \\
\text { 2018) (Sowjanya \& } \\
\text { Venugopalan, 2018) }\end{array}$ & India & $\begin{array}{l}\text { The study was } \\
\text { conducted in } \\
\text { January } 2016 \text { to } \\
\text { June } 2016 \text { which } \\
\text { aims to predict a 6- } \\
\text { week postpartum } \\
\text { mother to the } \\
\text { degree of exclusive } \\
\text { breastfeeding. }\end{array}$ & $\begin{array}{l}\text { Quantitative } \\
\text { (Prospective } \\
\text { Cohort } \\
\text { Study) }\end{array}$ & $\begin{array}{l}\text { LATCH } \\
\text { assessment tool }\end{array}$ & $\begin{array}{l}100 \text { pairs } \\
\text { of mothers } \\
\text { and chid } \\
\text { with } \\
\text { gestational } \\
\text { age aterm } \\
\text { from } \\
\text { vaginal } \\
\text { delivery. }\end{array}$ & $\begin{array}{l}\text { LACTH is a simple } \\
\text { valuation tool that is } \\
\text { economical and able to } \\
\text { predict numbers and the } \\
\text { duration of breastfeeding } \\
\text { early in life, especially in } \\
\text { areas with limited } \\
\text { resources. }\end{array}$ \\
\hline 4 & $\begin{array}{l}\text { LATCH Scores and } \\
\text { Milk Intake in Preterm } \\
\text { and Term Infants: A } \\
\text { Prospective } \\
\begin{array}{l}\text { Comparativer Study } \\
\text { (Nilgun Altuntas, }\end{array}\end{array}$ & Turki & $\begin{array}{l}\text { This study aims to } \\
\text { detect whether } \\
\text { premature infants } \\
\text { and term infants get } \\
\text { breast milk which } \\
\text { is sufficient and }\end{array}$ & $\begin{array}{l}\text { Quantitative } \\
\text { (Prospective } \\
\text { Cohort } \\
\text { Study) }\end{array}$ & $\begin{array}{l}\text { LATCH } \\
\text { assessment tool }\end{array}$ & $\begin{array}{l}66 \text { nursing } \\
\text { mothers } \\
(33 \\
\text { premature } \\
\text { and } 33 \\
\text { term }\end{array}$ & $\begin{array}{l}\text { Characteristics of high } \\
\text { LATCH scores ie; } 7 \text { to } \\
\text { 10. High LATCH scores } \\
\text { in premature babies and } \\
\text { term infants can detect } \\
\text { the amount of milk taken }\end{array}$ \\
\hline
\end{tabular}

Esti Rahayu, et.al (Efektivitas Skor Latch sebagai Alat Penilaian Menyusui....)

Copyright (@ 2021, Jurnal Kebidanan dan Keperawatan Aisyiyah ISSN 1858-0610 (print) | ISSN 2477-8184 (online) 


\begin{tabular}{|c|c|c|c|c|c|c|c|}
\hline No & $\begin{array}{l}\text { Title/Author } \\
\text { /Year/Score }\end{array}$ & Country & Objective & $\begin{array}{l}\text { Types of the } \\
\text { Research }\end{array}$ & $\begin{array}{l}\text { Data colleting } \\
\text { technique }\end{array}$ & $\begin{array}{l}\text { Participan } \\
\text { ts/Sample } \\
\text { size }\end{array}$ & Result \\
\hline & $\begin{array}{l}\text { Mesut Kocak, Serpil } \\
\text { Akkurt, Hasan Cem } \\
\text { Razi, and Mehmet } \\
\text { Fatih Kislal, 2015) } \\
\text { (Altuntas et al., 2015) }\end{array}$ & & $\begin{array}{l}\text { aims to determine } \\
\text { whether the } \\
\text { breastfeeding } \\
\text { technique } \\
\text { assessment tool can } \\
\text { detect enough } \\
\text { breast milk babies } \\
\text { according to age } \\
\text { and weight at birth }\end{array}$ & & & babies) & $\begin{array}{l}\text { around } 50 \% \text { of the } \\
\text { amount expected. } \\
\text { However, there are still } \\
\text { LATCH scores related to } \\
\text { variability in determining } \\
\text { the minimum amount and } \\
\text { maximum milk taken. }\end{array}$ \\
\hline 5 & $\begin{array}{l}\text { Predicting } \\
\text { Breastfeeding } \\
\text { Duration Using the } \\
\text { LATCH Breastfeeding } \\
\text { Assessment Tool (Jan } \\
\text { Riordan, Diane Bibb, } \\
\text { Marsha Miller dan } \\
\text { Tim Rawlins, 2001) } \\
\text { (Jan Riordan, 1998) }\end{array}$ & $\begin{array}{l}\text { Amerika } \\
\text { Serikat }\end{array}$ & $\begin{array}{l}\text { The purpose of this } \\
\text { study was to } \\
\text { determine the } \\
\text { length of } \\
\text { breastfeeding using } \\
\text { the LATCH score } \\
\text { assessment tool. }\end{array}$ & $\begin{array}{l}\text { Quantitative } \\
\text { (Prospective } \\
\text { Cohort } \\
\text { Study) }\end{array}$ & $\begin{array}{l}\text { Data were taken } \\
\text { from the medical } \\
\text { records of babies } \\
\text { who were not } \\
\text { treated } \quad \text { with } \\
\text { intensive care, } \\
\text { babies born } \\
\text { prematurely, } \\
\text { serotonus and } \\
\text { twins. }\end{array}$ & $\begin{array}{l}127 \\
\text { mothers } \\
\text { who } \\
\text { breastfeed } \\
\text { their } \\
\text { babies }\end{array}$ & $\begin{array}{l}\text { In the results of the } \\
\text { study found there is a } \\
\text { correlation between } \\
\text { LATCH steps. The } \\
\text { LATCH score is useful } \\
\text { for factor identifying } \\
\text { early cessation } \\
\text { breastfeeding. }\end{array}$ \\
\hline 6 & $\begin{array}{l}\text { Psychometric } \\
\text { Evaluation of 5-and 4- } \\
\text { Item Versions of the } \\
\text { LATCH Breastfeeding } \\
\text { Assessment Tool } \\
\text { during the Initial } \\
\text { Postpartum Period } \\
\text { among a Multiethnic } \\
\text { Population (Ying Lau, } \\
\text { Tha Pyai Htun, Peng }\end{array}$ & $\begin{array}{l}\text { Singapur } \\
\text { a }\end{array}$ & $\begin{array}{l}\text { To assess whether } \\
\text { the LATCH score } \\
\text { breastfeeding } \\
\text { assessment tool is } \\
\text { able to predict a } \\
\text { mother can } \\
\text { breastfeed her baby } \\
\text { before } 6 \text { weeks } \\
\text { postpartum and the } \\
\text { assessment is }\end{array}$ & $\begin{array}{l}\text { Cross- } \\
\text { sectional }\end{array}$ & $\begin{array}{l}\text { Data is taken from } \\
\text { September } 2013 \\
\text { to August } 2014 \text { in } \\
\text { Singapore tertiary } \\
\text { hospitals. Criteria } \\
\text { for respondents } \\
\text { taken were } \\
\text { women who gave } \\
\text { birth in } 2 \\
\text { puerperal wards }\end{array}$ & $\begin{array}{l}\text { The } \\
\text { number of } \\
\text { samples } \\
\text { are } 907\end{array}$ & $\begin{array}{l}\text { The LATCH score can be } \\
\text { used by health } \\
\text { professionals to assess } \\
\text { breastfeeding practice in } \\
\text { postpartum mothers. In } \\
\text { addition, the validity of } \\
\text { the LATCH score has } \\
\text { been tested so that it can } \\
\text { be used in all }\end{array}$ \\
\hline
\end{tabular}

Esti Rahayu, et.al (Efektivitas Skor Latch sebagai Alat Penilaian Menyusui....)

Copyright @ 2021, Jurnal Kebidanan dan Keperawatan Aisyiyah

ISSN 1858-0610 (print) | ISSN 2477-8184 (online) 


\begin{tabular}{|c|c|c|c|c|c|c|c|}
\hline No & $\begin{array}{l}\text { Title/Author } \\
\text { /Year/Score }\end{array}$ & Country & Objective & $\begin{array}{l}\text { Types of the } \\
\text { Research }\end{array}$ & $\begin{array}{l}\text { Data colleting } \\
\text { technique }\end{array}$ & $\begin{array}{l}\text { Participan } \\
\text { ts/Sample } \\
\text { size }\end{array}$ & Result \\
\hline & $\begin{array}{l}\text { Im Lim, Sarah Ho-Lim, } \\
\text { Piyanee dan Klainin- } \\
\text { Yobas, 2016) (Lau et } \\
\text { al., 2016) }\end{array}$ & & $\begin{array}{l}\text { carried out by a } \\
\text { professional officer } \\
\text { when hospitalized. }\end{array}$ & & $\begin{array}{l}\text { and } \\
\text { hospitalized. }\end{array}$ & & populations. \\
\hline 7 & $\begin{array}{l}\text { The LATCH Scoring } \\
\text { System and Prediction } \\
\text { of Breastfeeding } \\
\text { Duration (Savitri P. } \\
\text { Kumar, Roberta } \\
\text { Mooney, Linda J. } \\
\text { Wieser, dan Suzanne } \\
\text { Havstad, 2006) (Kumar } \\
\text { et al., 2006) }\end{array}$ & $\begin{array}{l}\text { Amerika } \\
\text { Serikat }\end{array}$ & $\begin{array}{l}\text { To determine } \\
\text { whether the } \\
\text { LATCH score } \\
\text { could be used as a } \\
\text { predictor of } \\
\text { breastfeeding } \\
\text { performed } \\
\text { inpatient by } \\
\text { professional staff at } \\
\text { the hospital. }\end{array}$ & $\begin{array}{l}\text { Quantitative } \\
\text { (Prospective } \\
\text { Cohort } \\
\text { Study) }\end{array}$ & $\begin{array}{lr}\text { Data was } & \text { taken } \\
\text { from } & \text { hospital } \\
\text { medical } & \text { record } \\
\text { data } & \text { and } \\
\text { conducted } & \\
\text { interviews } & \text { on all } \\
\text { samples. } & \end{array}$ & $\begin{array}{l}\text { The } \\
\text { number of } \\
\text { samples is } \\
188 \text {. Not } \\
\text { all mothers } \\
\text { who gave } \\
\text { birth were } \\
\text { breast-fed } \\
\text { and } \\
\text { hospitalize } \\
\text { d samples } \\
\text { because } \\
\text { many } \\
\text { mothers } \\
\text { were sent } \\
\text { home } 24 \\
\text { hours after } \\
\text { delivery. }\end{array}$ & $\begin{array}{l}\text { From the results of the } \\
\text { study found that there are } \\
66.5 \% \text { of mothers who } \\
\text { breastfeed their babies at } \\
6 \text { weeks postpartum. } \\
\text { LATCH scores are higher } \\
\text { among women who } \\
\text { breastfeed their babies } \\
\text { than those who have } \\
\text { weaned their babies. If a } \\
\text { breastfeeding mother } \\
\text { scores a high LATCH } \\
\text { score then she is } 1.7 \\
\text { times more likely to } \\
\text { breastfeed in the first } 6 \\
\text { weeks compared than } \\
\text { women with lower } \\
\text { scores. }\end{array}$ \\
\hline 8 & $\begin{array}{l}\text { Validity and Reliability } \\
\text { of the Infant } \\
\text { Breastfeeding } \\
\text { Assessment Tool, the } \\
\text { Mother Baby }\end{array}$ & Turki & $\begin{array}{l}\text { To evaluate the } \\
\text { validity and } \\
\text { reliability of a } \\
\text { breastfeeding } \\
\text { assessment tool. }\end{array}$ & Cohort study & $\begin{array}{l}\text { Postpartum } \\
\text { mothers who } \\
\text { deliver babies } \\
\text { atterm and are not } \\
\text { given intensive }\end{array}$ & $\begin{array}{l}46 \text { samples } \\
\text { were } \\
\text { randomly } \\
\text { selected } \\
\text { and } \\
\text { monitored }\end{array}$ & $\begin{array}{l}\text { This study had a } \\
\text { correlation between the } \\
\text { MBA, IBFAT and } \\
\text { LATCH breastfeeding } \\
\text { assessment tools. The test } \\
\text { results of these tools }\end{array}$ \\
\hline
\end{tabular}

Esti Rahayu, et.al (Efektivitas Skor Latch sebagai Alat Penilaian Menyusui....)

Copyright @ 2021, Jurnal Kebidanan dan Keperawatan Aisyiyah ISSN 1858-0610 (print) | ISSN 2477-8184 (online) 


\begin{tabular}{|c|c|c|c|c|c|c|c|}
\hline No & $\begin{array}{l}\text { Title/Author } \\
\text { /Year/Score }\end{array}$ & Country & Objective & $\begin{array}{l}\text { Types of the } \\
\text { Research }\end{array}$ & $\begin{array}{l}\text { Data colleting } \\
\text { technique }\end{array}$ & $\begin{array}{l}\text { Participan } \\
\text { ts/Sample } \\
\text { size }\end{array}$ & Result \\
\hline & \begin{tabular}{l}
\multicolumn{3}{l}{ Assessment Tool, } \\
and the LATCH \\
Scoring System (Nilgun \\
Altuntas, Canan \\
Turkyilmaz, Havva \\
Yildiz, Ferit Kulali, \\
Ibrahim Hirfanoglu, \\
Esra Onal, \\
Ebru Ergenekon, Esin \\
Koc, and Yildı \\
Atalay, 2014) (Altuntas \\
et al., 2014)
\end{tabular} & & & & care. & $\begin{array}{l}\text { and then } \\
\text { scored } \\
\text { simultaneo } \\
\text { usly. }\end{array}$ & $\begin{array}{l}\text { obtained minimum scores } \\
\text { on LATCH and IBFAT } \\
\text { and maximum scores on } \\
\text { LATCH and MBA. }\end{array}$ \\
\hline
\end{tabular}




\section{Arranging, summarizing and report results (stage 5)}

Data extracted from the articles obtained are then organized into several themes. The themes that have been included in the purpose of this article include the effectiveness and weakness of the LATCH score as a breastfeeding assessment tool. From 8 articles that are suitable and of good quality, data extraction is then carried out to find out in detail and classify a number of points from the article, such as the country of research, the purpose of the study, the methods used, and the results or findings of the research conducted. Of the 8 articles selected, 7 articles used the Cohort Prospective research method and 1 article used cross sectional.

\section{RESULTS AND DISCUSSION}

The articles obtained are from developed and developing countries, 3 articles from Turkey, 2 United States, 1 Italy, 1 India and 1 Singapore.
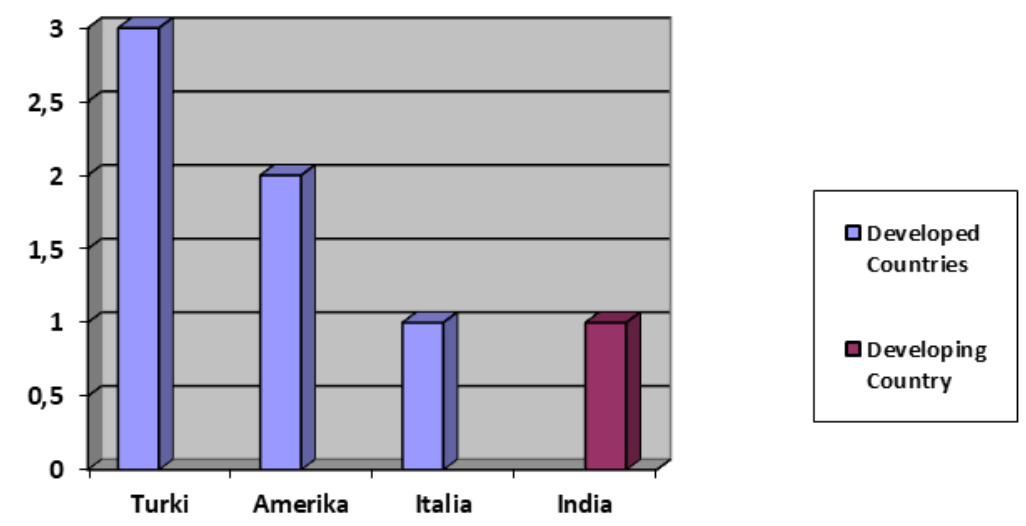

Figure 1. Country characteristics

\section{Finding}

\section{Effectiveness of the LATCH score as the assessment tool of breastfeeding}

Based on the research Cakmak \& Kuguoglu (2007) the LATCH score is an effective tool for assessing differences in breastfeeding technique and can plan the management needed (Tornese et al., 2012). LATCH scores can be used by health workers to assess the amount of breast milk a baby drinks and how breastfeeding is given to postpartum mothers so that the assessment is more objective. The study conducted (J Riordan et al., 2001) also suggested that the LATCH score could be used to identify nursing mothers who are at risk of early cessation breastfeeding because of sore nipples. The LATCH assessment tool is an effective tool as a simple predictor of breastfeeding duration (Kumar et al., 2006).

The LATCH score is an easy-to-understand, easy and inexpensive tool for objectively testing breastfeeding techniques, especially for areas with inadequate facilities and infrastructure. The LATCH score results can be used as an estimate of the duration of breastfeeding in newborns. If the results of the assessment are low, support and management are needed at home. The results of the assessment can be used to motivate mothers so that they are able to breastfeed exclusively (Sowjanya \& Venugopalan, 2018). This is reinforced by research (Altuntas et al., 2014) which conduct research on three breastfeeding assessment tools, namely 
LATCH, IBFAT and MBA where the results of the LATCH assessment tool are used effectively as a breastfeeding assessment tool.

\section{Weaknesses of the LATCH score as the assessment tool of breastfeeding}

Research (Lau et al., 2016) argue that the specificity or accuracy of the LATCH score is low on the comfort level of the mother while breastfeeding and the position of the baby, however it has a high sensitivity value which can be used to predict non-exclusive breastfeeding. Another weakness is in the research conducted by (Altuntas et al., 2015) which argue that the LATCH score cannot be used in premature babies due to its variability, thus, it can interfere with the assessment process because there are other factors that can affect it such as the strength of the tongue and mouth in breastfeeding.

\section{DISCUSSION}

The LATCH score is one of the most popular of lactation assessment instruments, this breastfeeding assessment tool was invented in 1994 in the United States by a nurse named Deborah Jensen and her team, their aim was to design this instrument to document the assessment of breastfeeding systematically (Jensen et al., 1994). Until now, relatively few studies have examined the effectiveness of the LATCH score, including the articles discussed in this scoping review.

\section{Effectiveness of the LATCH score as the assessment tool of breastfeeding}

Breastfeeding provides many short-term and long-term benefits for mother and child. Even though, breastfeeding is the duty of mother, the successful breastfeeding can be a complex task for both mother and baby in which the motivation and comfort affect the sustainability of breastfeeding (Maharani et al., 2018). Increasing breastfeeding promotion and support in maternity facilities and implementing the Baby-Friendly Hospital Initiative (BFHI) program and implementing the LATCH score can be an effective intervention, this is related to health professionals who will assist the breastfeeding mothers and it also needs an assessment of the LATCH score due to this aspect is truly associated with the success of breastfeeding practice (Tornese et al., 2012). In addition, research (Sowjanya \& Venugopalan, 2018) also states that the LATCH charting system is effective for breastfeeding assessment tools because of its simplicity in documentation and easy communication, in addition, the LATCH score is effective in predicting the success rate of exclusive breastfeeding that given at the time of newborn baby at hospitalization and it is continued to 6 weeks postpartum.

Breastfeeding is needed in the process of child growth and development. One of the ways in the world to prioritize breastfeeding is by promoting and providing support to breastfeeding mothers (Sakalidis \& Geddes, 2016). The results of an objective assessment of breastfeeding can be used as a solution to achieve successful breastfeeding practice, one of the important factors is involved in the success of breastfeeding, namely attachment, which is a factor in the LATCH breastfeeding assessment tool (Sowjanya \& Venugopalan, 2018). Another study conducted by (Altuntas et al., 2015) regarding the frequency of breastfeeding in preterm and term infants using the LATCH score assessment tool

Esti Rahayu, et.al (Efektivitas Skor Latch sebagai Alat Penilaian Menyusui....) 
found that if the score is more than 7 then the baby is breastfeeding approximately half of the expected amount of milk. Thus, from this study, the LATCH score assessment tool is effective in the use of preterm and term infants.

The LATCH score is also the second best of breastfeeding assessment tool after the Infant Breastfeeding Assessment Tools (IBFAT). However, many studies use the LATCH score compared to the IBFAT although the LATCH score ranks in the second, this is related to the conciseness of the assessment tool rather than the IBFAT score which is a tool developed to measure the breastfeeding behavior of term infants who have difficulty breastfeeding (Altuntas et al., 2015).

\section{The Weaknesses of the LATCH score as a breastfeeding assessment tool}

The score of LATCH cannot be used in preterm infants due to its variability. This is influenced by the unpredictable condition of the infants because there are other factors that may hinder the assessment of the breastfeeding process, such as the strength of the tongue and mouth in breastfeeding, thus, it is not necessary to assess the breastfeeding process to see the duration of breastfeeding for preterm infants (Altuntas et al., 2015). In addition, the LATCH score has a weakness in the point of Comfort (the comfort level of teacher) and Hold (the position of infant) because these points require questions deeply to assess (Lau et al., 2016). According (Altuntas et al., 2015) the LATCH score cannot be used in infants and mothers who are undergoing intensive care.

\section{CONCLUSION}

LATCH scores are used effectively for nursing practice assessment systems because they are systematic, can detect weaning early, are easy to use, concise, and cost-effective. The results showed that the LATCH score was effectively used for assessment tools for breastfeeding practice and also the LATCH score was the second best breastfeeding assessment tool after the IBFAT (Infant Breastfeeding Assessment Tools) for its effectiveness so that many studies used the LATCH score as a breastfeeding assessment tool compared to other assessment tools although has second place. Where the LATCH score is made with the aim to document the systematic and objective assessment of breastfeeding practices. LATCH scores can be used to assess breastfeeding practices for mothers who give birth vaginally or in caesarean section and also for term babies or premature babies. However, to assess the duration of breastfeeding in premature babies is not recommended.

\section{REFERENCES}

Abbas, I., \& Hasan, R. (2015). Assessment of LATCH tool regarding initiation of breastfeeding among women after childbirth. Assessment, 5(05), 38-44.

Altuntas, N., Kocak, M., Akkurt, S., Razi, H. C., \& Kislal, M. F. (2015). LATCH scores and milk intake in preterm and term infants: a prospective comparative study. Breastfeeding Medicine: The Official Journal Of The Academy Of Breastfeeding Medicine, 10(2), 96-101. https://doi.org/10.1089/bfm.2014.0042 
Altuntas, N., Turkyilmaz, C., Yildiz, H., Kulali, F., Hirfanoglu, I., Onal, E., Ergenekon, E., Koç, E., \& Atalay, Y. (2014). Validity and reliability of the infant breastfeeding assessment tool, the mother baby assessment tool, and the LATCH scoring system. Breastfeeding Medicine: The Official Journal Of The Academy of Breastfeeding Medicine, 9(4), 191-195. https://doi.org/10.1089/bfm.2014.0018

Arksey, H., \& Malley, L. O. (2005). Scoping studies: towards a methodological framework. 19-32.

Brown, C. R. L., Dodds, L., Legge, A., Bryanton, J., \& Semenic, S. (2014). Factors influencing the reasons why mothers stop breastfeeding. Canadian Journal of Public Health, 105(3), 179-185. https://doi.org/10.17269/cjph.105.4244

Cakmak, H., \& Kuguoglu, S. (2007). Comparison of the breastfeeding patterns of mothers who delivered their babies per vagina and via cesarean section: an observational study using the LATCH breastfeeding charting system. International Journal Of Nursing Studies, 44(7), 1128-1137. http://search.ebscohost.com/login.aspx ?direct=true \&db=mnh\&AN=1683955 $7 \&$ site $=$ ehost-live

Dennis, C.-L., Gagnon, A., Hulst, V. A., \& Dougherty, G. (2012). Predictors of breastfeeding exclusivity among migrant and Canadian-born womn: result from a multi-centre study. Maternal and Child Nutrition, 4(01), 33-54.

Heird, W. C. (2012). Infant nutrition. Present Knowledge in Nutrition: Tenth Edition, 624-636. https://doi.org/10.1002/9781119946045.ch40

Jensen, D., Wallace, S., \& Kelsay, P. (1994). LATCH: a breastfeeding charting system and documentation tool. Journal Of Obstetric, Gynecologic, And Neonatal Nursing: JOGNN, 23(1), 27-32. http://search.ebscohost.com/login.aspx?direct=true \&db=mnh\&AN=8176525 $\&$ site $=$ ehost-live

Kumar, S. P., Mooney, R., Wieser, L. J., \& Havstad, S. (2006). The LATCH scoring system and prediction of breastfeeding duration. Journal Of Human Lactation: Official Journal Of International Lactation Consultant Association, 22(4), 391-397. http://search.ebscohost.com/login.aspx?direct=true \&db=mnh\&AN=1706278 $4 \&$ site $=$ ehost-live

Lau, Y., Htun, T. P., Lim, P. I., Ho-Lim, S., \& Klainin-Yobas, P. (2016). Psychometric evaluation of 5- and 4-item versions of the LATCH breastfeeding assessment tool during the initial postpartum period among a multiethnic population. Plos One, 11(5), e0154331-e0154331. https://doi.org/10.1371/journal.pone.0154331

Maharani, F., Nisman, W. A., \& Lismidiati, W. (2018). Gambaran perlekatan ibu- 
bayi selama menyusui di Puskesmas Mantrijeron dan Umbulharjo 1. Skripsi diterbitkan. Yogyakarta: Universitas Gadjah Mada.

Kementerian Kesehatan Republik Indonesia. (2014). Profil Kesehatan Indonesia 2014. Jakarta: Kementerian Kesehatan Republik Indonesia.

Riordan, J, Bibb, D., Miller, M., \& Rawlins, T. (2001). Predicting breastfeeding duration using the LATCH breastfeeding assessment tool. Journal Of Human Lactation: Official Journal Of International Lactation Consultant Association, $17(1), \quad 20-23$. http://search.ebscohost.com/login.aspx?direct=true \&db=mnh\&AN=1184784 $7 \&$ site $=$ ehost-live

Riordan, Jan. (1998). Predicting breastfeeding problems. AWHONN Lifelines, 2(6), 31-33. $\quad$ https://doi.org/https://doi.org/10.1111/j.15526356.1998.tb01049.x.

Sakalidis, V. S., \& Geddes, D. T. (2016). Suck-Swallow-Breathe dynamics in breastfed infants. Journal of Human Lactation, 32(2), 201-211. https://doi.org/10.1177/0890334415601093

Sowjanya, S. V. N. S., \& Venugopalan, L. (2018). LATCH score as a predictor of exclusive breastfeeding at 6 weeks postpartum: a prospective cohort study. Breastfeeding Medicine: The Official Journal of The Academy Of Breastfeeding Medicine, 13(6), 444-449. https://doi.org/10.1089/bfm.2017.0142

Tauriska, T. A. (2015). Hubungan antara isapan bayi dengan produksi ASI pada ibu menyusui di Rumah Sakit Islam Jemursari Surabaya. Jurnal Ilmiah Kesehatan, 8(1), 15-21.

Tornese, G., Ronfani, L., Pavan, C., Demarini, S., Monasta, L., \& Davanzo, R. (2012). Does the LATCH score assessed in the first 24 hours after delivery predict non-exclusive breastfeeding at hospital discharge? Breastfeeding Medicine: The Official Journal Of The Academy Of Breastfeeding Medicine, 7(6), 423-430. https://doi.org/10.1089/bfm.2011.0120

UNICEF, W. and. (2019). Increasing commitment to breastfeeding through funding and call to action priorities. 2017-2019. https://apps.who.int/iris/bitstream/handle/10665/326049/WHO-NMH-NHD19.22-eng.pdf?ua=1

Wagner, E. A., Chantry, C. J., Dewey, K. G., \& Nommsen-Rivers, L. A. (2013). Breastfeeding concerns at 3 and 7 days postpartum and feeding status at 2 months. Pediatrics, 132(4), 865-875. https://doi.org/10.1542/peds.20130724 